\title{
IMPLIKASI KEBIJAKAN RUANG TERBUKA HIJAU DALAM PENATAAN RUANG DI JAWA BARAT
}

\author{
Nadia Astriani \\ Fakultas Hukum Universitas Padjadjaran \\ e-mail : nadia.astriani@unpad.ac.id
}

\begin{abstract}
Green Open Space (RTH) diminishing lead to the emergence of insecurity and social diseases and influence the improvement of micro-climate, air pollution, floods, and various other negative environmental impacts. The study was conducted by looking at the green open space in a holistic manner. This method is expected to explain the policy of the green space in West Java and the policy implications of the Spatial Plan. Research results indicate the overall amount of green space in West Java has not fulfilled the amount of $30 \%$ as mandated by the Law on Spatial Planning, so the RTH policy directed at meeting the quota of $30 \%$, with a range of strategies for improving the quality and quantity of green space Regency/City. RTH is an important part of City Spatial System, the procurement of green space is part of planning in the protection and management of the environment. As part of the layout, RTH is an instrument of prevention of pollution and/or damage to the environment.
\end{abstract}

Keywords: Policy, Green Open Space, Spatial

\begin{abstract}
abstrak
Ruang Terbuka Hijau (RTH) yang semakin berkurang menimbulkan munculnya kerawanan dan penyakit sosial serta berpengaruh terhadap peningkatan iklim mikro, pencemaran udara, banjir, dan berbagai dampak negatif lingkungan lainnya. Penelitian dilakukan dengan melihat kebijakan ruang terbuka hijau secara holistik. Metode ini diharapkan dapat menjelaskan mengenai kebijakan RTH di Provinsi Jawa Barat dan implikasi kebijakan tersebut terhadap Rencana Tata Ruang Wilayah. Hasil Penelitian menunjukan keseluruhan jumlah RTH di Jawa Barat belum memenuhi jumlah 30\% sebagaimana yang diamanatkan oleh Undang-Undang Penataan Ruang, sehingga kebijakan RTH diarahkan pada pemenuhan kuota 30\%, dengan berbagai strategi peningkatan kualitas dan kuantitas RTH Kabupaten/Kota. RTH merupakan bagian penting dari Sistem Tata Ruang Kota, maka pengadaan RTH merupakan bagian perencanaan dalam perlindungan dan pengelolaan lingkungan hidup. Sebagai bagian dari tata ruang, RTH merupakan instrumen pencegahan pencemaran dan/atau kerusakan lingkungan hidup.
\end{abstract}


Kata Kunci : Kebijakan, Ruang Terbuka Hijau, Tata Ruang

\section{A. Pendahuluan}

Ruang tidak dapat dipisahkan dari manusia baik secara psikologis, emosional, ataupun dimensional. Manusia berada dalam ruang, bergerak. Menghayati, dan berpikir, juga membuat ruang untuk menciptakan dunianya. Dalam perencanaan kota, ruang kota harus dibedakan oleh suatu karakteristik yang menonjol seperti kualitas detail dan aktivitas yang berlangsung didalamnya. Komponen utama perancangan kota terdiri dari dua kategori, yakni ruang keras dan ruang lembut. ${ }^{1}$ Ruang terbuka yang merupakan ruang yang direncanakan untuk kebutuhan pertemuan dan aktivitas bersama di udara terbuka masuk ke dalam komponen ruang lembut.

Sampai saat ini, pemanfaatan ruang masih belum sesuai dengan harapan yakni terwujudnya ruang yang nyaman, produktif, dan berkelanjutan. Menurunnya kualitas permukiman di perkotaan bisa dilihat dari kemacetan yang semakin parah, berkembangnya kawasan kumuh yang rentan dengan bencana banjir/longsor, serta semakin hilangnya ruang terbuka (Openspace) untuk artikulasi dan kesehatan masyarakat.

Berdasarkan KTT Bumi di Rio de Janeiro, Brazil (1992) dan dipertegas lagi pada KTT Johanesburg Afrika Selatan 10 tahun kemudian (2002), disepakati bersama bahwa sebuah kota idealnya memiliki luas RTH minimal $30 \%$ dari total luas kota. Namun tampaknya bagi kota-kota di Indonesia pada umumnya hal ini sulit direalisasikan akibat tekanan pertumbuhan penduduk dan kebutuhan sarana dan prasarana kota, seperti pembangunan bangunan gedung, pengembangan, dan penambahan jalan yang terus meningkat.

Pasal 1 angka 31 Undang-Undang No. 26 Tahun 2007 tentang Penataan Ruang mendefinisikan Ruang Terbuka Hijau (RTH) sebagai area memanjang/jalur dan/atau mengelompok yang penggunaannya lebih bersifat terbuka, tempat tumbuh tanaman, baik yang tumbuh secara alamiah, maupun yang sengaja ditanam. Klasifikasi Ruang Terbuka Hijau (RTH) dapat dibagi menjadi: ${ }^{2}$

1. kawasan hijau pertamanan kota;

2. kawasan hijau hutan kota;

3. kawasan hijau rekreasi kota;

4. kawasan hijau kegiatan olahraga; dan

5. kawasan hijau pemakaman.

\footnotetext{
${ }^{1}$ Eko Budihardjo dan Djoko Sujarto, Kota Berkelanjutan, Bandung: PT. ALUMNI, hlm. 63, 74, dan 91.

${ }^{2}$ Hasni, Ruang Terbuka Hijau dalam Rangka Penataan Ruang, hlm. 229.
} 
Pasal 1 angka 2 Permendagri No. 1 Tahun 2007 tentang Ruang Terbuka Hijau kawasan Perkotaan mendefinisikan Ruang Terbuka Hijau Kawasan Perkotaan (RTHKP) sebagai bagian dari ruang terbuka suatu kawasan perkotaan yang diisi oleh tumbuhan dan tanaman guna mendukung manfaat ekologi, sosial, budaya, ekonomi, dan estetika.

Permasalahan Ruang Terbuka Hijau di Kota/Kabupaten Jawa Barat terdiri atas:

1. perkembangan kota yang pesat, sehingga banyak terjadi peralihan fungsi lahan dari kawasan budidaya pertanian menjadi kawasan permukiman;

2. sebagian besar RTH Privat pada pertanian perkotaan sudah beralih fungsi menjadi lahan terbangun (komersil);

3. sempadan sungai yang ada di wilayah perencanaan hampir sebagian besar menjadi daerah terbangun;

4. jalur hijau yang berada di kecamatan Sumedang Utara masih kurang, baik secara kuantitas maupun kualitas (jenis vegetasinya);

5. kesadaran masyarakat sebagai bagian dari stakeholder kurang paham dan peduli akan pentingnya RTH, walaupun ada kebanyakan belum bisa menjaga dan memelihara RTH yang ada, seperti taman lingkungan perumahan;

6. RTH di bawah Jaringan SUTT dan SUTET belum sepenuhnya dapat dibebaskan, sehingga masih banyak dipergunakan fungsinya untuk selain RTH;

7. penanganan RTH yang belum dilakukan secara maksimal dengan melibatkan swasta dan masyarakat;

8. keberadaan lapangan parkir terbuka tidak dibarengi dengan penghijauan/penanaman pohon pelindung, sehingga termasuk kriteria ruang terbuka saja;

9. keberadaan pelaku ekonomi/PKL di sekitar kawasan taman kota menyebabkan terganggunya tanaman atau vegetasi yang ada;

10.RTH Privat, khususnya untuk pekarangan perumahan masih kurang, hal ini terlihat dari banyaknya rumah yang menghabiskan seluruh luas kavling lahannya untuk dibangun rumah sehingga tidak memiliki pekarangan;

11.belum ada tindakan yang tegas dari pihak berwenang/terkait bagi pelanggar atau perusak RTH yang ada; serta

12.kurangnya sosialisasi mengenai RTH oleh instansi terkait kepada masyarakat, sehingga menyebabkan masih banyak RTH Privat yang tidak sesuai dengan ketentuan yang berlaku.

Realita demikian melahirkan pertanyaan bagaimanakah bentuk kebijakan RTH di Jawa Barat dan bagaimanakah implikasi kebijakan tersebut terhadap RRTRW Jawa Barat? 


\section{B. Pembahasan \\ 1. Penataan Ruang dalam Pengelolaan Lingkungan}

Pembukaan Undang-Undang Dasar 1945 (UUD 1945) alinea keempat menyatakan bahwa negara Indonesia melindungi segenap bangsa Indonesia, seluruh tumpah darah Indonesia, dan memajukan kesejahteraan umum. ${ }^{3}$ Negara mempunyai tanggung jawab terhadap perlindungan dan pengelolaan lingkungan hidup (sumber daya manusia, sumber daya alam, dan sumber daya budaya). Lebih lanjut Pasal $28 \mathrm{H}$ ayat (1) UUD 1945 Amandemen Kedua menegaskan bahwa setiap orang berhak mendapatkan lingkungan hidup yang baik dan sehat.

Hukum Lingkungan adalah hukum yang berhubungan dengan lingkungan alam dalam arti seluas-luasnya. Ruang lingkupnya berkaitan dengan dan ditentukan oleh ruang lingkup pengelolaan lingkungan. Hukum lingkungan berpandangan dengan sifatnya yang tunggal dan pendekatannya utuh menyeluruh, semua komponennya senantiasa saling berhubungan dan mempengaruhi dan segenap unsur memperlihatkan keanekaragaman. ${ }^{4}$ Tata Ruang dan Lingkungan Hidup mengandung arti yang sangat luas tetapi sekaligus juga seringkali punya konotasi sempit terbatas pada perencanaan dan perancangan fisik semata-mata. Padahal sudah semenjak beberapa tahun yang lampau perencanaan kota dan daerah yang menekankan arti fisik, serba deterministic, dan menomorduakan manusia dengan segenap keunikan perilakunya, telah banyak mendapat kecaman.

Penataan ruang kota sungguh rumit dan pelik karena mau tidak mau menyangkut benturan antara pendekatan-pendekatan teknokratik komersial dan humanis. ${ }^{5}$ Proses perkembangan kota tidak statis melainkan selalu dinamis. Penduduk selalu berubah dan bergerak, seringkali susah ditebak, karena itu pola tata ruang kota yang terlalu ketat dan kaku, tidak bisa tanggap terhadap perubahan. Perencanaan kota 'open ended' yang luwes dan kenyal memungkinkan penjabaran nilai, kebutuhan, dan gaya hidup yang berbeda dalam suatu lingkungan yang dinamik dan kelompok-kelompok penghuni kota yang berdatangan akan dengan mudah menyesuaikan diri dan membentuk kembali secara kreatif organisasi ruang, waktu, makna, dan komunikasinya. ${ }^{6}$

Disahkannya Undang-Undang No. 26 Tahun 2007 tentang Penataan Ruang menyebabkan perlu diperbarui Rencana Tata Ruang Nasional maupun Rencana Tata Ruang Wilayah, karena terdapat beberapa perbedaan tahapan perencanaan yang harus dilakukan. Penataan Ruang adalah proses

\footnotetext{
${ }^{3}$ Lihat Pembukaan Undang-Undang Dasar 1945 Alinea keempat.

${ }^{4}$ Munadjat Danusaputro, Hukum Lingkungan Buku I: Umum, Cetakan Ketiga, hlm. 71.

${ }^{5}$ Eko Budihardjo dan Sudanti Hardjohubojo, Kota Berwawasan Lingkungan, hlm. 199-200.

${ }^{6}$ Ibid., hlm. 201.
} 
perencanaan tata ruang, pemanfaatan ruang dan pengendalian pemanfaatan ruang. Klasifikasi penataan ruang berdasarkan pasal 4 UUPR diklasifikasikan berdasarkan sistem, fungsi utama kawasan, wilayah administratif, kegiatan kawasan, dan nilai strategis kawasan. Hal ini menunjukan bahwa fungsi kawasan menjadi poin utama dalam merencanakan peruntukan lahan.

Asas penataan ruang adalah pemanfaatan ruang bagi semua kepentingan secara terpadu berdaya guna dan berhasil guna, serasi, selaras, seimbang, dan berkelanjutan. Asas lainnya adalah keterbukaan, persamaan, keadilan, dan perlindungan hukum. Adapun tujuan penataan ruang adalah:

a. terselenggaranya pemanfaatan ruang berwawasan lingkungan berlandaskan Wawasan Nusantara dan Ketahanan Nasional;

b. terselenggaranya pengaturan pemanfaatan ruang kawasan lindung dan kawasan budi daya; dan

c. tercapainya pemanfaatan ruang yang berkualitas (UU No. 24 Tahun 1992).

Penataan ruang wilayah/kawasan pada era otonomi daerah memiliki konsep dan karakteristik sebagai berikut

a. lebih menitikberatkan kepada pendekatan bottom-up;

b. melibatkan semua pelaku pembangunan (stakeholder);

c. transparan dalam perencanaan, implementasi, dan pengendalian;

d. memberi perhatian besar pada tuntutan jangka pendek;

e. realistis terhadap tuntutan dunia usaha dan masyarakat;

f. berwawasan luas, dengan perhatian terhadap kawasan yang lebih detail;

g. rencana dapat dijadikan pedoman investasi;

h. menjaga dan meningkatkan mutu lingkungan sambil mendorong dan memfasilitasi pembangunan; serta

i. mempunyai visi pembangunan dan manajemen pembangunan (applicable).

\section{Kebijakan Ruang Terbuka Hijau dalam Perencanaan Tata Ruang}

Ruang Terbuka Hijau (RTH) kota adalah bagian dari ruang-ruang terbuka (open spaces) suatu wilayah perkotaan yang diisi oleh tumbuhan, tanaman, dan vegetasi (endemik, introduksi) guna mendukung manfaat langsung dan/atau tidak langsung yang dihasilkan oleh RTH dalam kota tersebut yaitu keamanan, kenyamanan, kesejahteraan, dan keindahan wilayah perkotaan tersebut. Tipologi RTH berdasarkan bentuknya dibagi menjadi 2, yaitu RTH berbentuk kawasan atau areal dan RTH yang berbentuk jalur atau memanjang.

Grey (1996) mengklasifikasi bentuk-bentuk RTH sebagai taman kota (city park), lapangan terbuka/bermain (public squares), halaman gedung/pekarangan (ground of city building), pemakaman dan monumen, 
jalur hijau (streetsides) dan median jalan, sempadan kawasan limitasi (riparian areas), dan kawasan khusus (special areas). Sedangkan Lovejoy (1976) memasukan kriteria kawasan pertanian sebagai bagian dari ruang terbuka hijau. $^{7}$

Penyelenggaraan RTH Kota bertujuan menjaga kelestarian, keserasian, dan keseimbangan ekosistem perkotaan yang meliputi unsurunsur lingkungan, sosial dan budaya sehingga RTH Kota diharapkan dapat bermanfaat sebagai ${ }^{8}$ :

a. identitas kota, dengan menanam tanaman yang merupakan lambang suatu kota;

b. pelestari plasma nutfah, dengan menjadikan RTH Kota sebagai areal pelestarian di luar kawasan konservasi;

c. penahan dan penyaring partikel padat dari udara sehingga udara lebih bersih dan sehat;

d. mengatasi genangan air dengan menanam jenis tanaman yang mempunyai kemampuan evapotranspirasi tinggi;

e. produksi buah-buahan secara terbatas bagi masyarakat di sekitar RTH;

f. ameliorasi iklim;

g. pengelolaan sampah dengan mengfungsikan RTH Kota sebagai penyekat bau, penyerap bau, pelindung tanah hasil bentukan sekomposisi dari tanah, dan penyerap zat berbahaya dan beracun;

h. pelestarian air tanah dengan membangun RTH pada daerah resapan air dari kota yang bersangkutan;

i. penapis cahaya silau;

j. meningkatkan keindahan;

$\mathrm{k}$. habitat burung dengan menyediakan pepohonan sebagai tempat mencari makan dan tempat bersarang;

1. mengurangi stress; dan

m. mengamankan pantai dari abrasi. adalah $^{9}$ :

Beberapa faktor yang harus diperhatikan dalam pengelolaan RTH

a. fisik (dasar eksistensi lingkungan), bentuknya bisa memanjang, bulat, maupun persegi empat atau panjang atau bentuk-bentuk geografis lain sesuai geo-topografinya;

b. sosial, RTH merupakan ruang untuk manusia agar bisa bersosialisasi;

c. ekonomi, RTH merupakan sumber produk yang bisa dijual;

d. budaya, ruang untuk mengekspresikan seni budaya masyarakat; dan

\footnotetext{
${ }^{7}$ Dhini Dewiyanti, Ruang Terbuka Hijau Kota Bandung : Suatu Tinjauan Awal Taman Kota Terhadap Konsep Kota Layak Anak, Majalah Ilmiah UNIKOM, Vol. 7 no 1.

${ }^{8}$ Hasni, Op. Cit., hlm. 241-251.

${ }^{9}$ Ibid., hlm. 279.
} 
e. kebutuhan akan terlayaninya hak-hak manusia (penduduk) untuk mendapatkan lingkungan yang aman, nyaman, indah, dan lestari.

Ketentuan yang terkait dengan rencana penyediaan dan pemanfaatan ruang terbuka hijau pada Undang-Undang No. 26 Tahun 2007 tentang Penataan Ruang mulai diatur di dalam ketentuan muatan penyusunan Rencana Tata Ruang Wilayah Kota (Pasal 28). Di dalam pasal berikutnya disebutkan bahwa proporsi ruang terbuka hijau pada wilayah kota paling sedikit $30 \%$ dari luas wilayah kota, terdiri dari luas wilayah kota, terdiri dari ruang terbuka hijau publik sebesar $20 \%$, dan sisanya merupakan ruang terbuka hijau privat.

Proporsi 30 (tiga puluh) persen merupakan ukuran minimal untuk menjamin keseimbangan ekosistem kota, baik keseimbangan sistem hidrologi dan sistem mikroklimat, maupun sistem ekologis lain, yang selanjutnya akan meningkatkan ketersediaan udara bersih yang diperlukan masyarakat, serta sekaligus dapat meningkatkan nilai estetika kota. Adapun proporsi ruang terbuka hijau publik seluas minimal 20 (dua puluh) persen yang disediakan oleh pemerintah daerah kota dimaksudkan agar proporsi ruang terbuka hijau minimal dapat lebih dijamin pencapaiannya sehingga memungkinkan pemanfaatannya secara luas oleh masyarakat.

Inmendagri No. 14 Tahun 1988 tentang Penataan RTH di wilayah perkotaan mensyaratkan tersedianya taman lingkungan dan taman kota sebagai berikut:

a. setiap 250 penduduk tersedia satu taman seluas $250 \mathrm{~m}^{2}$. Taman ini merupakan taman lingkungan perumahan untuk melayani aktivitas balita, manula, dan ibu rumah tangga sehingga menjadi sarana sosialisasi penduduk di sekitarnya;

b. setiap 2500 penduduk tersedia satu taman seluas $1.250 \mathrm{~m}^{2}$. Taman ini untuk menampung kegiatan remaja seperti berolahraga atau kegiatan kemasyarakatan lainnya;

c. setiap 30.000 penduduk tersedia satu taman seluas $9.000 \mathrm{~m}^{2}$. Taman ini untuk melayani kegiatan masyarakat seperti pertunjukan musik atau kegiatan olahraga pada Minggu pagi, shalat Idul Fitri, pameran pembangunan, dan/atau kampanye di musim pemilu atau pilkada. RTH ini dapat pula berupa acara kegiatan pasif sehingga fasilitas utama yang disediakan hanya berupa kursi-kursi taman, jalur sirkulasi serta pohonpohon besar sebagai peneduhnya;

d. setiap 120.000 penduduk tersedia satu taman seluas $24.000 \mathrm{~m}^{2}$. RTH ini sudah dapat dikategorikan sebagai taman kota, untuk menampung berbagai kegiatan baik skala kota maupun skala bagian wilayah kota; dan

e. setiap 480.000 penduduk tersedia taman kota seluas $144.000 \mathrm{~m}^{2}$. Taman ini berupa komplek olahraga masyarakat yang dilengkapi dengan fasilitas olahraga dan fasilitas pendukung lainnya. 
Tujuan pembentukan RTH di wilayah perkotaan adalah ${ }^{10}$ :

a. meningkatkan mutu lingkungan hidup perkotaan dan sebagai sarana pengamanan lingkungan perkotaan; dan

b. menciptakan keserasian lingkungan alam dan lingkungan binaan yang berguna bagi kepentingan masyarakat.

Berdasarkan Permen PU No. 05/PRT/M/2008 tentang Pedoman Penyediaan dan Pemanfaatan RTH di Kawasan Perkotaan, menguraikan lebih teknis berbagai jenis RTH yang perlu dikembangkan melalui berbagai klasifikasi dan pendekatan sebagai berikut:

a. berdasarkan luas wilayah:

1) penyediaan luas RTHKP menjadi tanggung jawab pemerintahan kabupaten dan kota;

2) RTH di perkotaan terdiri dari RTH Publik dan RTH Privat;

3) proporsi RTH pada wilayah perkotaan adalah sebesar 30\%, yang terdiri dari $20 \%$ ruang terbuka hijau publik dan $10 \%$ ruang terbuka hijau privat;

4) RTHKP publik tidak dapat dialihfungsikan;

5) apabila luas RTH baik publik maupun privat di kota yang bersangkutan telah memiliki luas total lebih besar dari peraturan atau peraturan perundang-undangan yang berlaku, maka proporsi tersebut harus tetap dipertahankan keberadaannya;

6) proporsi luas 30\% dari luas wilayah kota ini dapat dicapai secara bertahap melalui pengalokasian lahan perkotaan secara tipikal;

b. berdasarkan jumlah penduduk, luas RTH diperoleh dengan mengalihkan antara jumlah penduduk yang dilayani dengan standar luas RTH perkapita sesuai kategorinya;

c. berdasarkan kebutuhan fungsi tertentu. Fungsi RTH dalam hal ini adalah sebagai berikut:

1) perlindungan dan/atau pengamanan seperti pengamanan para pejalan kaki;

2) sebagai sarana dan prasarana;

3) membatasi penggunaan lahan agar fungsi utama tidak terganggu, RTH kategori ini meliputi:

a) jalur hijau sempadan rel KA;

b) jalur hijau jaringan listrik tegangan tinggi; dan

c) RTH kawasan perlindungan setempat seperti RTH sempadan sungai, sempadan pantai dan RTH pengamanan sumber air baku/mata air.

RTH merupakan bagian penting dalam Sistem Tata Ruang Kota, dikarenakan RTH memiliki banyak fungsi yaitu fungsi edaphis, hidro-

\footnotetext{
${ }^{10}$ Hasni, Op Cit, hlm. 254-255, bandingkan dengan pasal 2 Permendagri no 1 thn 2007 tentang Penataan Ruang Terbuka Hijau Kawasan Perkotaan.
} 
orologis, klimatologis, protektif, higienis, edukatif, estetis, dan sosial ekonomi. Karena itu pengadaan dan pengelolaan RTH merupakan bagian dari perencanaan dalam perlindungan dan pengelolaan lingkungan hidup. Dalam pola pemanfaatan ruang, ada ruang yang didorong pengembangannya dan ada ruang yang dibatasi pengembangannya. RTH merupakan bentuk pemanfataan yang didorong pengembangannya. Sebagai bagian dari tata ruang, RTH merupakan instrumen pencegahan pencemaran dan/atau kerusakan lingkungan hidup. Target 30\% RTH yang menjadi amanat Undang-Undang Penataan Ruang menjadi dasar perencanaan tata ruang kota. Pencapaian target tersebut memerlukan kerjasama berbagai pihak, karena pengelolaan ruang terbuka hijau tidak hanya merupakan tanggung jawab satu pihak pemerintah saja, namun merupakan tanggung jawab dari berbagai pelaku terkait.

Undang-Undang No. 26 tahun 2007 tentang Penataan Ruang menyebutkan untuk luasan RTH perkotaan minimal 30\%, dengan rincian $20 \%$ RTH publik dan $10 \%$ RTH privat, karena itu pemerintah daerah harus menggalang sumber daya yang ada yaitu dengan mengajak masyarakat, pihak swasta dan lembaga lainnya untuk terlibat dalam pengelolaan RTH tersebut.

Adapun tugas masing-masing pihak dapat dibagi sebagai berikut:

a. tugas utama pemerintah dalam pengelolaan RTH Publik adalah:

1) merencanakan RTH baik sebagai bagian dari RTRW Kota/Kabupaten, RDTR, rencana tata ruang lainnya, ataupun rencana tata hijau;

2) mendata ketersediaan RTH;

3) menyediakan luasan, sebaran dan jenis RTH yang memadai;

4) membangun, memperbaiki, dan memelihara RTH publik sebagai salah satu komponen peningkat daya dukung dan daya tampung lingkungan dengan tetap mempertahankan fungsi ekologis yang diembannya;

5) memberikan penyuluhan kepada semua pihak akan pentingnya fungsi serta keberadaan RTH Publik dalam suatu kota sehingga komponen ini harus selalu menjadi bagian dari pembangunan suatu kota;

6) memfasilitasi pelaku pembangunan lainnya untuk berpartisipasi dalam pengelolaan RTH;

7) mendorong peran masyarakat dalam pengelolaan RTH baik secara perorangan maupun berkelompok dalam bentuk swasta/badan usaha atau lembaga;

8) mengendalikan dan membatasi alih fungsi lahan RTH menjadi kawasan terbangun; dan

9) menyusun program pengadaan RTH termasuk aspek pembiayaan dan instansi/pelaku pembangunan yang terlibat dalam program tersebut.

b. peran masyarakat dalam pengelolaan RTH diantaranya:

1) menjaga keberadaan RTH dengan cara: 
a) tidak membangun pada jalur sempadan sungai;

b) tidak mengubah fungsi taman yang ada;

c) tidak menebang pohon pada jalur hijau sempadan jalan.

2) memelihara RTH pada kawasan perumahan;

3) turut mengawasi proses pemeliharaan dan keberadaan RTH dengan memberi masukan kepada instansi pengelola jika terjadi penyimpangan penggunaan $\mathrm{RTH}$;

4) menyediakan lahan untuk penyelenggaraan $\mathrm{RTH}$;

5) memberikan bantuan dalam mengidentifikasi komponen RTH yang ada maupun yang potensial dikembangkan; dan

6) memberikan informasi, saran, pertimbangan, atau pendapat dalam penyelenggaraan RTH.

c. peran swasta dalam pengelolaan RTH, diantaranya:

1) menjaga keberadaan RTH dengan cara:

a) tidak membangun pada jalur sempadan sungai;

b) tidak mengubah fungsi taman yang ada; dan

c) tidak menebang pohon pada jalur hijau sempadan jalan.

2) berperan dalam pembangunan komponen RTH buatan dengan cara memberi dana pembangunan saja maupun turut sebagai pelaksana pembangunan/perbaikan taman;

3) memelihara taman dengan biaya pemeliharaan dan penyediaan tenaga kerja lapangan sendiri, namun memperoleh imbalan secara tidak langsung seperti pemasangan reklame;

4) menyediakan lahan untuk penyelenggaraan $\mathrm{RTH}$;

5) memberikan informasi, saran, pertimbangan, atau pendapat dalam penyelenggaraan $\mathrm{RTH}$; dan

6) memberikan bantuan dalam mengidentifikasi komponen RTH yang ada maupun yang potensial dikembangkan.

d. peran lembaga terkait lain dalam hal ini lembaga penelitian, perguruan tinggi, dan LSM adalah:

1) penyuluhan dan pendidikan lewat media;

2) penyuluhan ke sekolah-sekolah;

3) pencanangan gerakan bangun, pelihara, dan kelola RTH di tingkat RT sampai kecamatan;

4) menyediakan lahan untuk penyelenggaraan $\mathrm{RTH}$;

5) memberikan informasi, saran, pertimbangan, atau pendapat dalam penyelenggaraan $\mathrm{RTH}$; dan

6) memberikan bantuan dalam mengidentifikasi komponen RTH yang ada maupun yang potensial dikembangkan.

Agar keberadaan RTH tidak berkurang baik secara kualitas maupun kuantitas dan jumlah RTH publik dan privat mengalami peningkatan maka perlu dilakukan Pengendalian RTH. 
Pengendalian RTH dapat dilakukan melalui dua cara, yaitu :

a. pengendalian melalui perangkat peraturan, beberapa model peraturan yang bisa dikembangkan untuk mengendalikan RTH, baik secara langsung maupun tidak langsung, yaitu:

1) peraturan yang langsung mengatur tentang $\mathrm{RTH}$, antara lain:

a) peraturan zonasi untuk zona RTH (zoning ordinance);

b) peraturan tentang penghijauan/lanskap (landscape ordinance);

c) peraturan pengembangan ruang terbuka (open space development ordinance);

d) ketentuan tata penghijauan dan penghalang visual (landscaping and screening code); dan

e) peraturan daerah atau surat keputusan bupati tentang rencana induk penataan, pengelolaan, dan pengendalian RTH di wilayah Kota Sumedang.

2) pengaturan yang secara tidak langsung mengatur tentang $\mathrm{RTH}$, antara lain:

a) peraturan pengembangan lahan (land development regulation);

b) peraturan perpetakan (land subdivision);

c) peraturan perlindungan rawa dan badan air (water resources ordinance);

d) peraturan pengontrolan erosi dan sedimentasi (erosion and sedimentation control ordinance);

e) peraturan pengendalian limbah air hujan (storm water ordinance); dan

f) peraturan pematangan lahan (clearing and grading ordinance).

b. pengendalian melalui mekanisme administratif, dilakukan melalui caracara sebagai berikut:

1) pengendalian melalui perizinan dalam bentuk perizinan khusus;

2) pengendalian melalui pengawasan dan penertiban dan

3) pengendalian melalui insentif dan disinsentif.

\section{Penutup}

\section{Kesimpulan}

Kewenangan pengelolaan ruang terbuka hijau merupakan kewenangan yang dimiliki oleh pemerintah kota dan kabupaten. Sehingga kebijakan ruang terbuka hijau di Provinsi Jawa Barat, sangat dipengaruhi kebijakan ruang terbuka hijau di tingkat kabupaten dan kota. Secara keseluruhan jumlah RTH di Jawa Barat belum memenuhi jumlah 30\% sebagaimana yang diamanatkan oleh Undang-Undang Penataan Ruang, sehingga kebijakan RTH diarahkan pada pemenuhan kuota $30 \%$, dengan berbagai strategi peningkatan kualitas dan kuantitas RTH Kabupaten/Kota. Ruang Terbuka Hijau merupakan bagian penting dalam sistem tata ruang kota, dikarenakan RTH memiliki banyak fungsi yaitu fungsi edaphis, hidro-orologis, 
klimatologis, protektif, higienis, edukatif, estetis, dan sosial-ekonomi. Karena itu pengadaan dan pengelolaan RTH merupakan bagian dari perencanaan dalam perlindungan dan pengelolaan lingkungan hidup. Sebagai bagian dari tata ruang RTH merupakan instrumen pencegahan pencemaran dan/atau kerusakan lingkungan hidup. Sehingga dapat disimpulkan bahwa kebijakan mengenai RTH merupakan bagian dari kebijakan perlindungan dan pengelolaan lingkungan hidup. Sebagai bagian dari kebijakan perlindungan dan pengelolaan lingkungan hidup, kebijakan RTH sangat mempengaruhi Kebijakan Rencana Tata Ruang Wilayah Kota/Kabupaten, karena salah satu bentuk pengendalian RTH dilakukan melalui Rencana Tata Ruang Wilayah Kota/Kabupaten.

\section{Saran}

Melihat pentingnya fungsi RTH dalam kehidupan masyarakat, pemerintah perlu lebih giat mensosialisasikan tentang pentingnya RTH sehingga masyarakat turut serta dalam menjaga dan memelihara RTH publik yang ada. Dengan bekerjasama antara masyarakat dan swasta pemerintah dapat menambah RTH kota dengan adanya RTH Privat yang dibuat oleh masyarakat dan pihak swasta. Selain itu pemerintah juga perlu meningkatkan pengawasan dan memberikan sanksi tegas bagi perusak kawasan RTH. Pemerintah juga perlu mencari terobosan baru dalam meningkatkan RTH sehubungan dengan terbatasnya lahan yang ada, misalnya dengan membuat taman di atap bangunan-bangunan tinggi (roof garden).

\section{Daftar Pustaka}

\section{A. Buku}

Budihardjo, Eko, dan Djoko Sujarto, 2005. Kota Berkelanjutan, Cetakan Kedua, Bandung: PT, Alumni. , dan Sudanti Hardjohubojo, 2005. Kota Berwawasan Lingkungan, Cetakan Kedua, Bandung: PT Alumni.

Danusaputro, Munadjat, 2001. Hukum Lingkungan Buku I: Umum, Cetakan Ketiga, Bandung: Putra A Bardin.

Dewiyanti, Dhini, Ruang Terbuka Hijau Kota Bandung : Suatu Tinjauan Awal Taman Kota Terhadap Konsep Kota Layak Anak, Majalah Ilmiah UNIKOM, Vol 7 no 1.

Hardjasoemantri, Koesnadi, 1999. Hukum Tata Lingkungan, Edisi ketujuh Cetakan Keenam Belas, Yogyakarta: Gadjah Mada Univesity Press.

Hasni, 2008. Hukum Penataan Ruang dan Penatagunaan Tanah,Jakarta: Rajawali Pers. 
Kusumaatmadja, Mochtar, 1967. Hukum, Masyarakat dan Pembinaan Hukum Nasional, Bandung: Bina Cipta.

Mitchell, Setiawan, dan Dwita Hadi Rahmi, 2003. Pengelolaan Sumberdaya dan Lingkungan, Yogyakarta: Gadjah Mada University Press.

Nurlinda, Ida, 2009. Prinsip-Prinsip Pembaruan Agraria "Perspektif Hukum", Jakarta: Rajawali Pers.

Rasjidi, Lili, dan Ira Rasjidi, 2001. Dasar-Dasar Filsafat dan Teori Hukum, Bandung: Citra Aditya Bakti.

Soemitro, Ronny Hanitijo, 1988. Metodologi Penelitian Hukum dan Jurimetri, Jakarta: Ghalia Indonesia. 